\title{
The Effect of Lavender Aromatherapy on Labor Pain Among Delivery Women in Bandung 2020
}

\author{
Aqliya Alqonita Nursahidah, Shinta Novelia*, and Anni Suciawati \\ Universitas Nasional, Jl. Sawo Manila, Pejaten, Ps. Minggu, Jakarta 12520, Indonesia \\ *Corresponding author: shinta.novelia@civitas.unas.ac.id \\ Type of the Paper (Article)
}

Received: July 24, 2020; Accepted: August 27, 2020; Published: August 31, 2020

https://doi.org/10.29253/achnr.2020.21332

\begin{abstract}
This study aimed to analyze the effect of aromatherapy lavender on labor pain. Labor pain is a manifestation of cervical nerve compression. When there is pain, stress hormones cause the opening of the cervix is inadequate so that labor can increase in time. The way to deal with labor pain, which is one of them with non-pharmacological methods, aromatherapy lavender is known to contain linalool, that the main active ingredient could give relaxing effect to reduce pain and anxiety. This research used the quasi-experiment, with a post-test only control group design. The intervention group inhaled lavender aromatherapy for 30 minutes. The lavender essential oil dripped four drops in 50 milliliters $(\mathrm{ml})$ of water on diffuser aromatherapy, while the control group did not inhale. The sample in this study was 30 respondents in the first of the active phase. Labor pain assessment using a numeric rating scale. The normality test in both groups showed that the data were not normal. The Mann Whitney test showed $P$-value was $0.002<0.05$, so it could conclude that there was an effect of lavender aromatherapy on labor pain during the first of the active phase at the Afifah Clinic in Bandung Regency.
\end{abstract}

Keywords: Aromatherapy, Active Phase of Labor, Lavender Essential Oil, Labor Pain

\section{Introduction}

In general, childbirth is a long-awaited thing for women, but it can turn to despair when women experience labor pain. Labor pain is caused by uterine contractions, cervical dilatation, vaginal and pelvic floor stretching. It has been described as one of the most intense forms of pain. (Mortazavi et al., 2012). Also, if the labor pain is not under control, women can face certain risks like feelings of fear, anxiety, helplessness, and loss of control throughout the birthing process (Hull \& Simkin, 2011). Most of the women giving birth in Bandung experienced severe pain (91.9\%), caused by uterine contractions, stretching of the cervix, or opening the cervix to push the baby out (Legiati \& Widiawati, 2013).

One of the causes of prolonged labor is severe pain during labor, which could lead to the desire to immediately end labor and straining before maximal cervical dilatation, which could lead to cervical swelling, which results in uterine dystocia of labor (Hamilton, 2005). According to the Indonesian Demographic and Health Survey in 2014 that prolonged labor (42.96\%) was the main cause of maternal and perinatal death, followed by bleeding $35.26 \%$ and eclampsia $16.44 \%$. Labor pain can cause hyperventilation so that the demand for oxygen increases, increases in blood pressure, decreases intestinal and bladder motility. This situation can stimulate catecholamines hormone, which could disrupt the strength of uterine contractions resulting in uterine inertia that could result in maternal death 
during childbirth (Sumarah, 2009). One of the ways to lower the numbers morbidity of women, according to Regulation in 2014 no. 103 is to provide Services Health Traditional Complementary, one of them by using the herb that comes from the plant (Ministry of Health of Indonesia, 2014).

In granting methods pharmacological, the pain of labor will be reduced by physiological, but the condition of the psychological and emotional woman will be ignored (Makvandi, 2016). Nonpharmacological methods are effective without negative effect can increase satisfaction during childbirth because the woman can control their feelings (Maryunani, 2015). One method is aromatherapy which uses essential oils. Aromatherapy Lavender is an essential analgesic oil that contains $8 \%$ terpenes and $6 \%$ ketones. Monoterpene is a type of terpene compound that is most often found in plant essential oils. A high-quality lavender extract not only fits this monograph but ideally exceeds these specifications with a higher linalyl acetate (33-45\%) and lavandulyl acetate ( $\geq 1.5 \%)$ content, and a lower limit for cineol content which is an ester compound formed by combining organic acids and alcohols (Tarsikah, 2012).

Lavender oil is a fabulous multi-purpose essential oil. Because of its analgesic properties, it can be used to alleviate pain in different conditions such as changing dressings, palliative care, controlling labor pain as well as chronic pain. The linalyl acetate component of lavender can relax smooth muscles (Mohamed $\mathrm{M}$ et al., 2015). Linalool is the main active ingredient that plays a role in the anti-anxiety (relaxing) effect of lavender (McLain, 2009). According to a study (Janula R \& Manipal S, 2015) (Makvandi et al., 2016) (Tarsikah, 2012) (Vakilian et al., 2018) concluded that aromatherapy is beneficial in reducing labor pain that affects the duration of labor. The results of the study Annida, (2019) Lavender aromatherapy proved to be more significant in reducing pain intensity 0.87 points higher more than lemon aromatherapy, so this study used aromatherapy lavender as an option to find out effect aromatherapy lavender on labor pain based on a preliminary study of 10 postpartum women in Arjasari District, there were $70 \%$ of women who experienced severe pain during labor. Hence, researchers were interested in examining the Effect of Lavender Aromatherapy on the First Stage of Labor Pain in the Active Phase at Afifah Clinic in 2020.

\section{Methods}

This study used a quasi-experiment research method with a post-test only control group design. The population in this study is 60 women respondents who are on the active phase at Afifah Clinic in Mei to June 2020. The sampling technique used purposive sampling. The researcher chose respondents based on the inclusion and exclusion criteria set by the researcher. The inclusion criteria are primigravida or multigravida patients in the first stage of the opening cervix 4 to $6 \mathrm{~cm}$ physiological delivery. The exclusion criteria are that women had an allergy to lavender aromatherapy and women who had complications in that pregnancy. An instrument of the pain scale uses the numeric rating scale. Respondent in this research are 30 women with physiology labor at Pratama Afifah Clinic Bandung District from May to June 2020, there are used purposive sampling then get 15 respondents with intervention, and 15 respondents are control groups.

In the control group, measuring the pain scale $(N R S)$ after the respondent at the labor of the first stage in the active phase, opening cervix 4 to $6 \mathrm{~cm}$. In the intervention group, after assessing the opening cervix, then lavender aromatherapy was inhaled for 30 minutes at the opening of the cervix 4 to $6 \mathrm{~cm}$ after that, the pain scale was assessed using the numeric rating scale (NRS). The lavender essential oil of four drops is poured into an a diffuser that has been given $50 \mathrm{ml}$ of water first and connected with electricity so that it will evaporate the lavender aroma. Lavender essential oil is safe for pregnant and delivery women because they have a distribution permit from the Ministry of Health of the Republic of Indonesia with the number of Domestic Health Supplies (PKD) 20601910921. The analysis in this study contained a univariate analysis using the table of a frequency distribution of respondent data. The bivariate analysis uses the Shapiro-Wilk normality test because the sample $<50$ with a significance of $P$ value $<0.05$, then the Mann Whitney test was performed because the data were not normally distributed.

\section{Ethical Considerate}

This study has no conflict of interest. It has been approved by the Faculty of Health Science Ethics Committee with The Letter Number 219/D/SP/FIKES/V/2020 and Afifah Clinic with the letter Number 2905-110/KA/VII-2020. 


\section{Result}

Table 1 majority of respondents 20-35 years old in the intervention and control group. The majority of respondents are highschool educated, and the majority of respondents are primiparous in intervention and control group.

Table 1. Frequency Distribution of Characteristic Respondents in the Intervention and Control group

\begin{tabular}{lcccc}
\hline \multicolumn{1}{c}{ Characteristics } & \multicolumn{2}{c}{ Intervention group } & \multicolumn{2}{c}{ Control group } \\
\hline Age & Frequency & Percentage (\%) & Frequency & Percentage (\%) \\
<20 years & 2 & 13.3 & 1 & 6.6 \\
20-35 years & 12 & 80 & 13 & 86.6 \\
$>$ 35 years & 1 & 6.6 & 1 & 6.6 \\
Education & & & & \\
Middle School & 6 & 40 & 5 & 33.3 \\
High school & 8 & 53.3 & 6 & 40 \\
College & 1 & 6.6 & 4 & 26.6 \\
Parity & 13 & 86.6 & 12 & 80 \\
Primigravida & 2 & 13.3 & 3 & 20 \\
Multigravida & & & & \\
\hline
\end{tabular}

Table 2. Frequency Distribution of Pain Scale Labor in Intervention Group with Numeric Rating Scale

\begin{tabular}{lll}
\hline Pain Scale NRS & \multicolumn{2}{l}{$\begin{array}{l}\text { The scale of } \\
\text { Intervention Pain }\end{array}$} \\
\hline & $\mathrm{F}$ & $\%$ \\
\cline { 2 - 3 } No Pain (0) & 0 & 0 \\
Mild Pain (1-3) & 1 & 6.7 \\
Moderate Pain (4-6) & 11 & 73.3 \\
Severe Pain (7-9) & 3 & 20.0 \\
Very Severe Pain (10) & 0 & 0 \\
\hline Total & 15 & 100 \\
\hline
\end{tabular}

Table 2 shows that the mild pain scale 1 person (6.7\%). Moderate pain is the majority of an intervention group that was 11 respondents (73.3\%). Severe pain just 3 respondents (20\%).

Table 3. Frequency Distribution of Pain Scale Labor in Control Group with Numeric Rating Scale

\begin{tabular}{lll}
\hline Pain Scale NRS & \multicolumn{2}{l}{$\begin{array}{l}\text { The scale of Pain } \\
\text { Control }\end{array}$} \\
\hline & $\mathrm{F}$ & $\%$ \\
\cline { 2 - 3 } No Pain (0) & 0 & 0 \\
Mild Pain (1-3) & 0 & 0 \\
Moderate Pain (4-6) & 9 & 60 \\
Severe Pain (7-9) & 6 & 40 \\
Very Severe Pain (10) & 0 & 0 \\
\hline Total & 15 & 100 \\
\hline
\end{tabular}

Table 3 shows the control group did not get respondents with mild pain scale (0\%). Moderate pain is 9 respondents (60\%). Severe pain is 6 respondents (40\%). Results Bivariate analysis in this study aimed to examine the effect of lavender aromatherapy on labor pain in the active phase. Shapiro Wilk normality test results show that the intervention group with sig .028 and in the control group .010, it can be concluded that the data are not normally distributed. Thus the Mann Whitney U test was performed. 
Table 4. Differences of Labor Pain between Intervention and control group in Active Phase at Afifah Pratama Clinic

\begin{tabular}{llllll}
\hline Group & Mean & $\begin{array}{l}\text { Standard } \\
\text { Deviation }\end{array}$ & Mean Rank & $\begin{array}{l}\text { Sum of } \\
\text { ranks }\end{array}$ & P-value \\
\hline Intervention & 5.87 & 1.252 & 10.80 & 162.00 & 0.002 \\
Control & 1.50 & 0.509 & 20.20 & 303.00 & \\
\hline
\end{tabular}

* Mann Whitney Test

Table 4 shows the mean of interventions group $5.87 \mathrm{SD}=1.252$ between control group 1.50 $\mathrm{SD}=0.509$. The mean rank of pain intensity in the intervention group 10,80 was smaller than the mean rank of pain intensity in the control group 20.20. Results of test Mann Whitney that $P$-value $=0.002$ $(<0.05)$. Thus, it was concluded that $\mathrm{H} 0$ was rejected, or that there was an influence of lavender aromatherapy on labor pain in the active phase I of the intervention group.

\section{Discussion}

As stated in the research by Tarsikah, (2012), it is one of the essential analgesic oils containing $8 \%$ terpene and $6 \%$ ketone. Monoterpene is the type of terpene compound most often found in plant essential oils. In medical applications, monoterpenes are used as sedatives. Lavender oil also contains $30-50 \%$ linalyl acetate. Linalyl acetate is an ester compound formed by combining organic acids and alcohols. Esters are very useful for normalizing emotional states and unbalanced body states, and also have properties as a sedative and tonic, especially in the nervous system. The essence produced by lavender aromatherapy will stimulate the thalamus to release encephalin, functioning as a natural painkiller. Enkephalin is a neuromodulator that functions to inhibit physiological pain.

There are several differences between any research with this research. Especially in the research methods of (Hetia et al., 2017), (Karlina et al., 2015), (Lamadah \& Nomani, 2016), (Susilarini, 2017) using quantitative research used a quasi-experiment method with one group pre-test and post-test design. However, in this research, the design used a post-test control group design, which that intervention and control group as a comparison. In this study, we conducted purposive sampling to provide inclusion and exclusion criteria. The inclusion criteria of respondents were carried out at 4 to $6 \mathrm{~cm}$ cervical opening. Since if the opening cervix is $10 \mathrm{~cm}$, the woman had to concentrate more to prepare herself to push and delivery (Baker A \& Ferguson, 2001) the opening cervix less than $7 \mathrm{~cm}$ of maternity women can still be good in communicate that is important when taking pain level data with NRS scale.

The results showed the average labor pain intensity based on the Numeric Rating Scale (NRS) instrument in the intervention group (who were given lavender aromatherapy) an average value of 10.8, the pain intensity in the control group (not given aromatherapy) an average value 20.2. Lavender aromatherapy in the intervention group was given for 30 minutes by 4 drops in $50 \mathrm{cc}$ of water as done in the (Sholehah et al., 2020) research, aromatherapy of rose essential oil was given to the woman for 30 minutes inhalation. According to the research of (Zahra \& Leila M, 2013) that the administration of lavender aromatherapy by inhalation is 4 drops of lavender essential oil in $50 \mathrm{cc}$ of water can affect to the labor pain.

Shapiro Wilk normality test concluded that the data are not normally distributed. Thus the Mann Whitney U test was performed. From the average, it can be seen that the difference in value is 10.8 lower than 20.2, with an average difference of 9.4. The results of the Mann Whitney test with a P-value of 0.002 $<0.05$ concluded that there is a difference in pain intensity which is meaningful between the intervention group and the control group, it shows that there is an effect of lavender aromatherapy on labor pain in the first phase of the active phase in Afifah Clinic, Bandung Regency. The results of this study are in accordance with research conducted by (Janula \& Manipal, 2015) about the effects of lavender aromatherapy on changes in labor pain intensity in 60 respondents. It was found that there was a significant effect on pain intensity and duration of the labor in the aromatherapy group. (Hetia et al., 2017 ) concluded that $P$-value $<0.05$, then there is an effect of lavender aromatherapy on the reduction of labor pain in the active phase. 
Women giving treatment with lavender aromatherapy mostly in moderate pain on labor there is 29 respondents (87.9\%), after receiving treatment with lavender aromatherapy mostly the pain decrease to 26 respondents $(78.8 \%$ ) (Susilarini et al., 2017). Similarity with this study, the intervention group who experienced mild pain with the control group there was no difference. The difference was also found in the intensity of severe pain in the intervention group, only $3(20 \%)$ respondents while in the control group $6(40 \%)$ respondents. This shows the difference in labor pain in the intervention group and the control group, according to (Batbual, 2010) mild pain shown by the characteristics of the client can communicate well.

The intrinsic mechanism in the first stage of labor pain occurs entirely in the uterus and adnexa during contractions. Different nerves deliver pain in each phase of labor. Labor pain in the first stage mainly originates from the uterus Labor pain causes fear and stress. Stress in the woman will cause the release of stress hormones such as catecholamines and steroids, resulting in reduced maternal blood flow to the fetus (Judha, 2015). The results of this study stated that there is an effect of lavender aromatherapy on labor pain. Lavender oil is one of aromatherapy, which is known to have a calming effect. Research conducted on humans on the effects of lavender aromatherapy for relaxation, anxiety, mood, and alertness to the activity of EEG (Electro Enchepalo Gram) shows a decrease in anxiety, mood improvement, and an increase in the strength of alpha and beta waves in the EEG which shows increased relaxation. The results also obtained a significant increase in the strength of alpha waves in the frontal region, which indicates an increase in drowsiness. (Yamada et al., 2005).

According to researchers' assumptions, inhalation of aromatherapy lavender during labor affects the scale of labor pain. The labor pain scale of the intervention group was low compared between the control group or women who were not inhaled aromatherapy lavender during labor. Lavender aromatherapy could reduce anxiety and fear before delivery. It can cause prolonged labor. The aromatherapy of lavender can control the sensation of pain during uterine contractions, which can increase levels of endorphins and epinephrine in the body to reduce pain during contractions in labor.

This research was conducted with several limitations that may affect the research results. The limitations of this study are due to technique sampling, using purposive sampling. Respondents were chosen based on the inclusion and exclusion criteria set by the researcher. A limited time of the study and the respondents who came to the Primary Afifah Clinic were dominated by primigravida women, 25 respondents, and 5 multigravida respondents. Because the respondents still not specific, so that the perception of pain is still not as diverse. According to (Hutahean, 2009) that the pain in one labor compared to the pain in the next labor will be different, because the difference in the mechanism of the cervical opening is that the primipara Ostium Uteri Internum will open first so that the cervix will flatten and thin out.

In primigravida women, 20 respondents experienced severe pain during the first phase of the active phase as much as $61.5 \%$, and 20 respondents in multigravida women experienced severe pain during stage 1 active phase is $38.5 \%$ (Saryono, 2012). Nevertheless, there is a gap of opinion between these theories with Ayu and Supliyan, (2017) that parity does not affect pain. The results also showed that the majority of respondents (62.5\%) were multigravida, meaning they had previous childbirth experience and had experience in dealing with pain in previous labor. Statistical test results showed that there was no significant relationship between maternal parity with the intensity of the first stage of labor pain, $p$ value> 0.05 .

\section{Conclusions}

There is an effect of lavender aromatherapy on labor pain in the active phase among delivery women. Educational institutions can apply this theory to the education curriculum. For health worker or midwife need to provide aromatherapy to reduce labor pain for the patient or woman delivery because it affects labor pain. The government can might revision policies or guidelines regarding complementary therapy. Further research is needed to explore the effect aromatherapy on labor pain by randomization sampling. 


\section{References}

Annida. (2019). R. Z.Efektivitas aromaterapi lavender dan aromaterapi lemon terhadap penurunan nyeri persalinan kala i fase aktif di Klinik Pratama Kusuma Medisca, Undergraduate Thesis, UNISA Yogyakarta.

Ayu, N. G., \& Supliyan, E. (2017). Karakteristik Ibu Bersalin Kaitannya dengan Intensitas Nyeri Persalinan Kala 1 di Kota Bogor. Jurnal Kebidanan, 3(4), 2014-2010.

Baker, A., Ferguson. (2001). Perceptions of labour pain by mothers and their attending midwives. Journal of Advanced Nursing, 35(2), 171-179.

B, Batbual. (2010). Hypnosis Hypnobirthing nyeri persalinan dan berbagai metode penanganannya. Yogyakarta: Gosyen Publishing.

Hamilton, P. (2005). Dasar Dasar Ilmu Keperawatan Maternitas. Jakarta: EGC

Hetia, N. E., Ridwan M., \& Herlina. (2017). Pengaruh aromaterapi lavender terhadap pengurangan nyeri persalinan kala I aktif. Jurnal Kesehatan Metro Sai wawai X(1), 5-10.

Hull \& Simkin. (2011). Pain, suffering, and trauma in labor and prevention of subsequent posttraumatic stress disorder. Journal of Perinatal Education, 20(3): 166-176.

Hutahean, S. (2009). Asuhan Keperawatan dalam Maternitas dan Ginekologi. Jakarta: TIM

Janula, Raju., \& Manipal, Singh. (2015). Effectiveness of aromatherapy and biofeedback during Childbirth in between primigravida. Health Science Journal, 9(1:9), 1-5.

Judha., Mohamad., et al. (2015). Teori Pengukuran Nyeri \& Nyeri Persalinan. Yogyakarta: Nuha Medika.

Karlina, S. D., Reksohusodo, S., \& Widayati, A. (2015). Pengaruh pemberian aromaterapi

lavender secara inhalasi terhadap penurunan intensitas nyeri persalinan fisiologis pada primipara inpartu kala satu fase aktif di BPM "Fety Fathiya" Kota Mataram. Majalah Kesehatan, 2(2), 108119.

Ministry of Health of Indonesia. (2014). Profil Kesehatan Indonesia Tahun 2014. Jakarta: Ministry of Health of Indonesia.

Makvandi, Somayeh., Mirteimoori, Masoumeh., Najmabadi, K. M., \& Sadeghi, R. (2016). A randomized clinical trial review of influence aromatherapy with lavender in labor pain relief. Medcrave Nursing \& Care Open Access Journal, 1(3), 42-47.

Lamadah, SM \& Ibtesam, N. (2016). Effects of aromatherapy massage using lavender oil on pain and anxiety during childbirth between primigravida women. American Journal of Nursing Science, $5(2), 37$.

Maryunani, A. (2015). Nyeri Dalam Persalinan. Jakarta: TIM.

McLain, DE. (2009). Chronic Health Effects Assessment of Spike Lavender Oil. Walker Doney and Associates.

Mohamed M., Hadayat A., Ragaa A., Sally A. (2015). Effectiveness of Aromatherapy with Lavender Oil in Relieving Post Caesarean Incision Pain: Journal of Surgery; 3(2-1): 8-13.

Mortazavi SH., Khaki S., Moradi R. (2012). Effects of massage therapy and presence of attendant on pain, anxiety and satisfaction during labor. Arch Gynecol Obstetri. DOI 10.1007/s00404-012-2227-4.

Saryono cited in Andriani. (2018). Pemberian prosedur teknik relaksasi nafas dalam untuk meningkatkan adaptasi pada nyeri melahirkan kala 1 pada ibu primigravida dengan persalinan normal RSUD Wangaya Tahun 2018. Available at http://repository.poltekkes-denpasar.ac.id/651/2/BAB\%201\%20pdf.pdf

Sholehah, K.S., Lisa, T.A., Ashar, N.P. (2020). Pengaruh Aromaterapi Minyak Atsiri Mawar terhadap Intensitas Nyeri Persalinan Kala 1 Fase Aktif di Puskesmas Pangalengan kabupaten Bandung. Jurnal Klmiah Kesehatan12 (1). Available at: http://journal.thamrin.ac.id/index.php/jikmht/article/view/116

Sumarah. (2009). Perawatan ibu bersalin. Yogyakarta: Fitramaya.

Susilarini., Winarsih S., Idhayati RI. (2017). Pengaruh Pemberian Aromaterapi Lavender terhadap Pengendalian Nyeri Persalinan Kala I pada Ibu Bersalin. Jurnal Kebidanan 6 (12). Available at: http://ejournal.poltekkes-smg.ac.id/ojs/index.php/jurkeb/article/view/1912

Tarsikah., Susanto, H. \& Sastramihardja, H.S. (2012). Penurunan NyeriPersalinan Primigravida Kala I Fase Aktif Pasca Penghirupan AromaterapiLavender di Rumah Bersalin Kasih Ibu Tuban. Diambil dari:www.digilib.unpad.ac.id/ file=pdf/abtrak-124684.pdf. 
Vakilian, K., Afsaneh, K., Maryam Gharacheh. (2018). Controlled Breathing with or without Lavender Aromatherapy for Labor Pain in Phase One: Randomized Clinical Trials Journal of Medical and Biological Sciences 5(3). Available at: http://www.cjmb.org/uploads/pdf/pdf_CJMB_176.pdf

Widiawati, I \& Legiati, T.(2013). Mengenal Nyeri Persalinan pada Primipara dan Multipara. Poltekkes Kemenkes bandung. Jurnal BIMTAS 2(1). Available at: http://repository.poltekkesbdg.info/items/show/2023

Yamada, K., Mimaki, Y., Sashida, Y. (2005). Effect Inhaling of the Vapor of Lavandula burnatii superDerrived Esensial Oil and Linalool on Plasma Adrenocorticotropin Hormone (ACTH), Catecholamine and Gonadotropin Level in Experimental Menopausal Female Rats. Pharmaceutical Society of Japan28(2): 1-18.

Zahra Abbaspoor., Mohammadkhani, SL. (2013). Lavender Aromatherapy Massage in Reducing Labor Pain and Duration of Labor: A randomized controlled trial. African Journal of Pharmacy 7 (8), pp. 426-430. available at: http://www.academicjournals.org/AJPP. DOI: 10.5897/AJPP12.391 